\title{
Problems and Prospects of sustainable tourism in the Republic of Kazakhstan
}

\author{
Piratdin Allayarov (Corresponding author) \\ School of Economics and Trade, Hunan University, 410006, Changsha, China \\ E-mail: pikon2003@mail.ru
}

Bakhit Embergenov

Department of Learning and Writing Center

Alexander College, BC V6B 1P2, Vancouver, Canada

Si Thu Han

School of Economics and Trade, Hunan University, 410006, Changsha, China

Received: February 18, 2018 Accepted: March 2, 2018 Published: April 5, 2018

doi:10.5296/ber.v8i2.12951

URL: https://doi.org/10.5296/ber.v8i2.12951

\begin{abstract}
This survey attempts to identify the existing problems faced by the tourism sector of the Republic of Kazakhstan and to identify the government policies initiated for the betterment of the tourism sector of the country. The methods of data collection, which were used are interviews from the travel and tour agents for the identification of the problems faced by the tourism industry of Kazakhstan and survey from the board members of the tourism companies of Kazakhstan. The method was used to reach logical conclusions and catered individual considerations in line with the research question. Recommendations to propose ways in which the government can improve the sector are given. The impact of sustainable tourism sector on the economy and financial health of Kazakhstan is presented.
\end{abstract}

Keywords: Tourism industry, Sustainable tourism, Kazakhstan, Government policy

\section{Introduction}

Geographically, the Republic of Kazakhstan is the 9th largest country in the world. The tourism sector of Kazakhstan has contributed approximately $0.3 \%$ to the Gross Domestic 
Product (GDP) of Kazakhstan, as per the data compiled in 2014 (Costa, Panyik, \& Buhalis, 2014). However, the growth in GDP contribution is expected to clock in at $1.6 \%$ or $\$ 3.08$ billion to the economy of Kazakhstan as per the statistical records of World Economic Forum (WEF) in their report of competitiveness presented in 2017. Moreover, the government of Kazakhstan is optimistic about the GDP growth, and it has been forecasted that the GDP is expected to grow to notable $3 \%$ by the year 2020 . Furthermore, the tourism industry of the Republic of Kazakhstan has also been ranked 81st for the calendar year 2017, by the World Economic Forum. There has been an improvement in the ranking of four times as compared to the previous ranking of WEF.

Globally, the tourism industry has posted decent growth owing to the growth of other economic sectors such as chemical, automobile, petroleum etc. and the impact of global growth has also been witnessed in the Republic of Kazakhstan. It is logically viewed that the growth in the tourism industry has its impact on the global economy at large because increase in tourism activity in any country brings handy foreign exchange to that particular country and it serves as a tool to support the balance of payments (Leamer, E. E., \& Storper, M. 2014). The growth witnessed in the tourism sector of Kazakhstan, has resulted in favourable changes to the country's balance of payment, supported the company's foreign trade deals and has also created employment opportunities for the youth of Kazakhstan. Moreover, the government has also initiated infrastructural developments to attract tourists, and this has also resulted in improving the overall superstructure and infrastructure of the country.

The Republic of Kazakhstan likewise the other central Asian countries have strategically utilized tourism for driving the economic growth. Welcoming foreign visitors not only brought the foreign exchange to the country but also enabled the government to efficiently decide on its economic and political choices.

Major export bills of Kazakhstan include the export of raw materials and government has installed a few controls over its export prices, as an initiative to reduce its reliance on the petroleum sector which has been the revenue generator analogous to the Gulf countries (Basher, Haug, \& Sadorsky, 2017). The government with an intention to fuel the economy has taken various steps to develop the energy sector of Kazakhstan with an objective of achieving economic diversity. The economic development and stable economic position of the country are likely to affect the sustainable development of the tourism industry. As there have been serious fluctuations in the international oil prices, the government's policy to reduce its economic reliance on petroleum sector is welcomed by the tourism industry as well. According to the statistics of World Trade Organization, it is concluded that if the Asian destinations are economically developed and stabilized, then it is likely that the rich tourists across the globe may also prefer to visit the Central Asian countries more frequently, including Kazakhstan, and these destinations may supersede the European destinations. Due to the important political and economic positioning of Kazakhstan, this can be very beneficial for the tourism industry of Kazakhstan, provided that the government of Kazakhstan continue its policies to develop the country structurally and economically.

International Tourism has increased over the year in the Republic of Kazakhstan (Gössling, 
Scott, \& Hall, 2015). As per the statistical records, there were around 1.47 million of tourists who visited the Republic of Kazakhstan in 2000. However, the number of international tourists visiting Kazakhstan significantly increased to approximately 4.81 million for the calendar year 2012. It has been viewed that the infrastructure of Kazakhstan is not developed and it is largely debated that based on the tourist attractions, which the country has in shape of desert and lake landscapes, attractive mountains and lush green outskirts, the tourism industry of Kazakhstan has not managed to achieve its true potential.

Problems with the tourism industry of Kazakhstan are dependent on various factors such as the lack of supply chain, and logistics facilities, underdeveloped infrastructure and low standard services to the tourists. Moreover, one of the notable problems faced by the economical tourists are the high prices which become a hurdle when the tourists plan to visit Kazakhstan. The problem for high prices is not only faced by the international tourists, but also by the local people of Kazakhstan, who have responded negatively by arguing that it costs almost half of their local spending when they visit places other than Kazakhstan for holiday vacations (Dzhusibalieva, 2016). However, international tourists still prefer to visit Kazakhstan despite these problems, and there have also been visits of the various celebrities and famous people like Prince Harry of Britain, who visited the country for the attractive skiing opportunities in the country.

The government of Kazakhstan has introduced various policies and formulated the "Tourism Industry Development Plan 2020" to address the problems of the tourism. According to this plan, the government plans to develop five regions of Kazakhstan, i.e. East Kazakhstan, West Kazakhstan, Astana City and Almaty City (Nasiri et al., 2016). Furthermore, the government also expects that through the "Tourism Industry Development Plan 2020" an investment of approximately $\$ 4$ billion will be made to better respond to the tourism problems and this plan would also result in the creation of three hundred thousand jobs.

Due to the Soviet Union's dissolution, Kazakhstan has emerged as a famous place for the tourists, and this gave rise to the need for formulation tourism friendly governmental policies. It has been argued that before the Soviet Union's dissolution, there was less competition and the tourism avenues of the USSR were far behind the European tourism standards. The initial years of Kazakhstan after the dissolution of USSR were challenging, where all the sectors needed immediate aid. The tourism sector of Kazakhstan struggled, and the GDP contribution stood as follows:

Table 1. Tourism share in Kazakhstan's GDP

\begin{tabular}{|c|c|}
\hline Year & Tourism share in Kazakhstan's GDP (\%) \\
\hline 1991 & $0.3 \%$ \\
\hline 1992 & $0.09 \%$ \\
\hline 1993 & $0.06 \%$ \\
\hline 1994 & $0.08 \%$ \\
\hline
\end{tabular}

However, on account of the favourable governmental policies and initiatives, the share of tourism in national GDP had steadily increased and by 2012 was improved to $0.68 \%$ and the 
country's ranking was also improved to 54th in the world.

The aims and objectives of this research are to identify the problems and prospects of Sustainable Tourism in Kazakhstan. The government of Kazakhstan after the independence of Kazakhstan from the Soviet Union has introduced various initiatives for solving the issues of the tourism sector of the country. However, there are still some issues which are unaddressed. If appropriate measures are taken such as the Tourism and Development Plan 2020, the tourism sector would flourish and result in high revenue generation for the country. This research aim at providing a detailed analysis of the existing tourism setup by identification of the current problems together with the prospects of the future of the industry. The aims of this research gives rise to the objectives mentioned below:

- To identify the existing problems faced by the tourism sector of the Republic of Kazakhstan;

- To identify the government policies initiated for the betterment of the tourism sector of the country;

- To propose ways in which the government can improve the sector;

- To identify the impact of sustainable tourism sector on the economy and financial health of Kazakhstan.

\section{Literature Review}

To attract tourists, it is essential that the tourism industry develop and equipped with the necessary tools depending on the type of people who visit the tourist places within a country. The country which has been chosen for this research study in Kazakhstan. It is imperative to mention here that Kazakhstan is a country which has a strong backing of history and culture. According to Hiro, et al., (2011), after the division of the Soviet Union, Kazakhstan was known as the central region in Central Asia.

According to Mustafayeva, et al., (2012), the majority of the population is Muslim and makes up around $47 \%$ of the total population of Kazakhstan. Therefore, it is essential to develop Islamic tourism within the country. Because the development of tourism is at the initial stage, there are various sectors which are yet to be developed. The values on which tourism industry is to be developed are Islamic religious and cultural values. Furthermore, it was identified that the tourism potential of Kazakhstan should be assessed through different attributes of cultural and natural development of the country. As the various regions of the Republic of Kazakhstan are different from each other, therefore, the tourism industry of Kazakhstan has great potential to develop. Tourists from across the globe is attracted to Kazakhstan due to its geographical position as well.

The Republic of Kazakhstan is not a famous tourism spot and is not most preferred by the foreign tourists and the tourists in Central Asia. However owing to its history and being part of the famous Soviet Union, there are numerous historical places which attract the tourists who have the eagerness to explore the remaining of the famous Soviet Union. According to Tiberghien, et al., (2014), it is imperative to analyze the way public and private sectors 
market the cultural and historical heritage of Kazakhstan, because it would directly result in an inclination of the various tourist to the country.

The role of significant tourist associations for addressing various tourist related issues and in particular to overcome the problems of sustainable tourism in Kazakhstan are handled by the tourism board under the Republic of Kazakhstan, which is an advisory body. The purpose of the council's work is to create development proposals to overcome the problems of sustainable tourism in Kazakhstan (Ivona, 2015), as well as recommendations on the coordination of the new government of the nation, aimed at enhancing the development of the country's tourist complex. The Council, in particular, is responsible for the development of congress and exhibition and the simplification of the visa regime of Kazakhstan with other countries. To overcome the problems of sustainable tourism in Kazakhstan, the tourist cameraman activity, and tour operator activity are made sufficient to formulate appropriate tourist packages. Moreover, the promotional activities of the tour agents are also closely examined to overcome the problems of sustainable tourism in Kazakhstan.

According to Masalimova, Omirbekova, \& Alikbayeva, (2014), various exhibitions which take place around the globe are the images of political and cultural backgrounds of any country. Therefore, it is imperative that various exhibitions should be organized, which will result in the development of the tourism industry of Kazakhstan. One of the recent examples is the expo 2017 in Kazakhstan. Events like the recent expo bring not only the valuable foreign exchange within the country, but also contribute to sustainable development of the tourism industry within the country, because when the visitors attend such expos, it results in their revisits of the country.

Tourists across the globe travel through different means of transportation, and one of the popular modes of transportation among the young tourists is the use of bicycle. According to Mamrayeva, D., \& Tashenova, L. (2017), in Kazakhstan there are very few cycling facilities, and the infrastructure for cycling in those facilities is not up to date either. Moreover, due to the lack of relevant literature on bike sharing, cycling and insufficient statistical data has made the bicycling tourists refrain from touring to Kazakhstan.

According to Zhidkoblinova, O., Stavbunik, Y., \& Spanova, B. (2016), owing to the financial downturn of 2008, the various private and public sector bodies operating in the country of Kazakhstan partnered for the promotion of sustainable tourism within the country. Development of tourist's products in various world and domestics markets is the task of the governments coupled with promoting a tourist-friendly environment. Appropriate resources required for the support of prospects of sustainable tourism in Kazakhstan include priority directions, the guidance of desired routes and appropriate tour packages for the tourists (Ospanov 2012).

\section{Methodology}

Since Kazakhstan is yet to be explored and has higher tourism potential it is imperative to design and formulate appropriate research methods to unfold the potential of the tourism industry and tourist products of the Republic of Kazakhstan. Appropriate research approach 
would be aimed at identifying the weaknesses of the regulatory policies that become a hurdle in the development of the industry. In this regard, the hypothesis can be carried out that would clarify the appropriate marketing strategies, relevant tourist products and services and necessary measures to be taken for promotion of the tourism industry of Kazakhstan. The research method is linked to the collection of data and subsequent analysis. In the context of our research question, the data can be collected by surveying the various management personnel serving the boards of the tourism companies of Kazakhstan. The viewpoints generated from the survey can identify the various problems being faced by the tourism industry and can also provide the future course of direction for sustainably developing the industry. For example, appropriate research could identify that owing to technological advancement the introduction of multi-agent technology could address the issues of analytical procurement.

In this study, qualitative research methods are used to investigate important data and incorporate the findings of each program into the test. It incorporates a qualitative approach in the survey of distributions available so far, a time lapse of particular importance and academic value. The qualitative approach is to accumulate data thinking about the component in a deep and meticulous way. In general, this is done in a central meeting, interviews and open interviews. As per our research question, various interviews would be conducted by the people who have toured Kazakhstan, and the replies from the respondents would be documented to better identify the problems and prospects for sustainable tourism in Kazakhstan. The motivation behind the qualitative approach is to produce a better way to see current data. If the design is to assemble the hypothetical structure or hypothesis, the researchers replicated the authenticity of the points of view or the consequences of the previous investigation; it is possible that it has help methods to reveal the reality of the assumptions.

\subsection{Data Collection}

In this study, the methods of data collection, which were used are interviews from the travel and tour agents for the identification of the problems faced by the tourism industry of Kazakhstan and survey from the board members of the tourism companies of Kazakhstan. We choose July and August to collect data from tourists as this is the best season to visit Kazakhstan. Therefore we choose random sample from 230 tourists in 2017. The method was used to reach logical conclusions and catered individual considerations in line with the research question. Using interviews as data collection method is highly likely to produce a wider response. Moreover, as interviews were conducted as a part of data collection process to identify the problems and prospects of sustainable tourism direct communication with the respondent's allowed relevant answers.

\subsection{Interview Process}

In this survey, inductive methods were used to evaluate the opinions of the respondents. This is the method that begins with the last stages of a logical investigation and often perceives and works backwards to form a theory. In this study, members visited the various travel agencies, owned by various travel agents across Kazakhstan. The view was expressed that 
members had sufficient ideals for the research approach and that they had adequate potential to observe research interests.

An interview between two or more interviewees is a verbal communication transaction. An ideal interview depends on the interviewer's communication skills and capabilities. Relevant interview questions in the context of our research area would be:

- Were the tourists offered to visit the various historical remnants of the Soviet Union in Kazakhstan?

- What measures can be taken to make travelling convenient for the tourists to revisit Kazakhstan?

- Are there promotions and packages attractive enough to convert one time travellers into frequent travellers to Kazakhstan?

\section{Discussion and Analysis}

Analysis of the data is usually made through data plans including tapes or sticky notes. If a tape chronicle occurs, the data is translated first literally. If it should not be observed and the researchers explain the chronic recorded, mixed notes usually interspersed with the transcripts, they often use different text styles, so the researcher can correctly recognize the sound of the data from the sound source. At this stage of the research, reading carefully all the information gathering is beneficial, so that scientists can get all the miraculous image that is examined. In this deep reading, part of the knowledge and understanding begin to develop and become a warning.

In the context of our research, it can be analyzed that the tourism industry of Kazakhstan has all the potential for tourism development. According to a research survey, around two hundred twenty-seven thousand tourists visited Kazakhstan in the five-year period.

After the dissolution of the Soviet Union, the GDP contribution of the tourism sector witnessed an alarming downside the Republic of Kazakhstan. However, the government has introduced various policies for the betterment of the tourism sector. One of the initiatives is the issuance of a visa-free regime, according to which the tourists from different countries such as Belarus, Mongolia, Ukraine, Russia. Georgia, Armenia, Azerbaijan, South Korea, Turkey, Argentina, Serbia, Uzbekistan and Kyrgyzstan can visit the Republic of Kazakhstan on a 90-day visit. Moreover, after the notable response of the visa-free regime, the government has further introduced a visa-free regime for another 45 countries including UAE, New Zealand, USA, OECD Member states and the European Union member states.

To assess the tourism sector of any country, we consider the three factors which are wage fund, tax revenue and some jobs. Moreover, the sustainability of the sector is analyzed by comparing the three factors. These factors are also called the principles of the sustainable tourism. Therefore, it is imperative that the policies formulated by the government of Kazakhstan should address the above mentioned principles. The terminology "sustainable tourism" is not widely known in various countries including Kazakhstan and it not even used at the government level. However, there is the presence of the similar terminologies such as 
the "Nature tourism", "Responsible Tourism", "Green tourism" and", "Soft tourism".

The prospects of the tourism industry of Kazakhstan rely on the regulations of the government which should be based on the regional tourism and its promotion. Over the recent years, the government's strategy to promote tourism has been clear, and this is evident from "Tourism Industry Development Plan 2020" and the following initiatives taken by the government:

- Introduction of law on tourism and its adoption effective from 13 June 2001.

- Development and creation of pilot clusters through government's resolution 25 June 2005.

- Amount of investment in the tourism industry has also been increased to 63 billion Kazakhstani tenges for the year 2018.

As stated previously, the terminology of sustainable development in the tourism sector is not widely used. Moreover, eco-tourism is familiar to people in Kazakhstan, but not as widespread as in western countries. Moreover, the various tour operators present in Kazakhstan use the "eco" term as a part of their marketing strategy to set higher prices for their tour packages.

\section{Conclusion and Recommendations}

\subsection{Conclusion}

Provided that the government has made efforts to develop the tourism sector after the independence of Kazakhstan from the Soviet Union. Still, the tourism sector of Kazakhstan needs the strategic focus of the government. One of the major reasons why the tourism sector is considered as underdeveloped is that "tourism" is still not recognized as an economic activity in the jurisdiction of Kazakhstan. Moreover, to develop the tourism sector, it is imperative that the government promote education so that the local workforce become competent enough to cater to the needs of the international tourists. It is essential that vocational courses must be offered to the youth of Kazakhstan to promote this kind of education. This would lead them to be competent enough in areas that are important for tourism. Moreover, the concept of on-the-job training must also be introduced so that the existing workforce should possess the required skills related to tourism. Furthermore, various seminars should be arranged to conduct various debates for the promotion and development of the tourism industry in the country.

Promotion of tourism studies must include innovation strategies and the way through which the tourism industry can be innovated. Tourism packages should possess appropriate pricing and marketing strategies to attract the domestic and international tourists. Moreover, to better attract the tourists, it is essential that the tour operators adopt the digital marketing tools that give a good impression on the interested tourists to visit the beautiful places of Kazakhstan. Using appropriate graphics and sceneries as marketing tools create a desire in the almost-interested tourists to travel to a country and explore. 
Government benefits in terms of tax exemptions to the various travel-related parties such as the airline companies, foreign travel agencies, bank and financial institutions may potentially increase the number of people travelling to Kazakhstan. Moreover, the payments should also be streamlined. Furthermore, improving the visa filling process coupled with the improvements in the airport infrastructure suitable for international travelling, such as employing only those staff at the Kazakhstan airport, who are fluent in the internationally spoken languages and also has sound tourism ethics, would lead to the growth of the tourism sector.

Globally, there are three ways to sustainably develop the tourism sector in any country which is to develop sustainable tourist locations, responsible tourists and sustainable economy or businesses. Sustainability should also be ensured in producing the services, and the consumption should also be made sustainable. The development process of the sustainable tourism relies on the appropriateness of these three factors. The countries who intend to sustainably develop their tourism sector should consider the idea of sustainable development as a key part of the long-term strategy serving as an integral part of the economic development as well. Continuous analysis of the statistical data should also be undertaken in the execution of the sustainable development of the tourism sector of Kazakhstan.

At present, there is an uncertainty in the sustainable development of the tourism industry of Kazakhstan, provided that there is a lack of familiarity with sustainable tourism in various institutions of Kazakhstan, let it be, the tour operators, or the administration and/or the government as a whole. The tourism sector is not innovation-driven and it is important that serious and immediate efforts should be taken by the government to sustainably develop Kazakhstan. Creating an environment of frequent usage of sustainable tourism terminology in the marketing campaigns of the tour operators, tourism forums, and governmental bodies may create tourism-related awareness in the society.

Furthermore, it can be concluded through the analysis of tourism sector of Kazakhstan, the development of the international inbound tourism has also been steady, but slower than expected. Therefore, efforts should be made in this regard. Lastly, it has been observed that the government's has also given low priority to developing the eco-friendly tourism mechanisms, and there is evidence where the government has violated the eco-tourism principles. It can also be noted that the product life cycle of eco-tourism is shorter and at present eco-tourism is in its declining phase of the product lifecycle in Kazakhstan. Therefore, appropriate efforts should be made in this regard, which would result in reviving the eco-friendly and ecological tourism in the jurisdiction of Kazakhstan.

\subsection{Recommendations}

Tourism sector of Kazakhstan has been a minor contributor to the Gross Domestic Product of the country. According to the data compiled for the year 2015, the tourism sector has contributed 662.9 billion Kazakhstani tenges, which made around 1.6\% of the total GDP figure. As per the estimates of the government, the figure would increase to notable 1,268.2 billion Kazakhstani tenges representing $1.8 \%$ of the Gross Domestic Product by the year 2026. The tourism sector is related to other industries such as the hotel industry, airline 
business, transportation and logistics industry. Therefore growth in the tourism sector would also drive the other industries of Kazakhstan. Although the Kazakh tour operators have efficiently handled the foreign inflow of people from time to time, yet, as per the outcome of our research we have identified various recommendations which are as follows: there is a limited number of tourism products, and appropriate product development would be sufficient to create attractiveness cluster. Moreover, favorable marketing strategies should be formulated by the public and private sector bodies aimed at promoting tourism of Kazakhstan. Presently the tour operators do not have appropriate forums where they can market their products competitively.

\section{References}

Baisakalova, A., \& Garkavenko, V. (2013). Trends in International Competitiveness of Tourism Industry in Kazakhstan. Global Community, 4, 271.

Baisakalova, A., \& Garkavenko, V. (2014). Competitiveness of tourism industry in Kazakhstan. Tourism in Central Asia: Cultural Potential and Challenges, 15-39. https://doi.org/10.1201/b17367-3

Basher, S. A. et al. (2017). The Impact of Oil-Market Shocks on Stock Returns in Major Oil-Exporting Countries: A Markov Switching Approach. [Online] Available: https://ssrn.com/abstract=3046052 (29 September 2017).

Costa, C. et al. (2014). European Tourism Planning and Organization Systems: The EU Member States. Bristol: Channel View Publications. ISBN.

Duissembayev, A. A., \& Abdykalykova, V. T. (2012). Prospects for the development of ecotourism in Kazakhstan. Education and Science without Borders, 6, 13-18.

Dzhusibalieva, A. et al. (2016). Prospects for a Green Economy in Tourism. The Journal of Internet Banking and Commerce, 21(3).

Gössling, S. et al. (2015). Inter-market variability in CO 2 emission-intensities in tourism: Implications for destination marketing and carbon management. Tourism Management, 46, 203-212. https://doi.org/10.1016/j.tourman.2014.06.021

Hiro, D. (2011). Inside Central Asia: A Political and Cultural History of Uzbekistan, Turkmenistan, Kazakhstan, Kyrgyzstan, Tajikistan, Turkey, and Iran. The Overlook Press. New York, United States.

Ivona, A. (2015). An analysis of sustainable tourism development in coastal areas of Albania. Interdisciplinary Journal of Research and Development, 3, 49-54.

Kapiki, S. T., \& Nurgaliyeva, S. (2015). Human Capital as an Important Asset of Kazakhstan's Sustainable Development. World Applied Sciences Journal, 33(3), 466-471.

Kuralbayev, A. et al. (2016). Organizational and economic problems in the management of the spiritual-Historical development of tourism in South Kazakhstan region. International Review of Management and Marketing, 6(2), 219-226. 


\section{$\Lambda$ Macrothink}

Business and Economic Research ISSN 2162-4860

Leamer, E. E., \& Storper, M. (2014). The economic geography of the internet age. In Location of International Business Activities, Palgrave Macmillan, London, United Kingdom, 63-93. https://doi.org/10.1057/9781137472311_4

Mamrayeva, D., \& Tashenova, L. (2017). Prospects of bicycle-sharing in urban tourism in the republic of Kazakhstan: Myth or reality? Transport Problems: an International Scientific Journal, 12(2), 65-76.

Masalimova, A., Omirbekova, A., \& Alikbayeva, M. (2014). EXPO 2017 is as a Strategic Objective of Cultural Policy. Procedia-Social and Behavioral Sciences, 143, 907-911. https://doi.org/10.1016/j.sbspro.2014.07.525

Mukhambetov, T. I., Janguttina, G. O., Esaidar, U. S., Myrzakulova, G. R., \& Imanbekova, B. T. (2014). The life cycle of sustainable eco-tourism: a Kazakhstan case study. WIT Transactions on Ecology and the Environment, 187, 39-49. https://doi.org/10.2495/ST140041

Mustafayeva, A. A., Nadirova, G. E., Kaliyeva, S. S., \& Aktaulova, B. Z. (2012). Developing Islamic Tourism in Kazakhstan: A Result of a Religious Revival or a New Trend of Tourism. Religion, International Scholarly and Scientific Research and Innovation, 6(11), 3277-3279.

Nasiri H. K. E., Hadavi, F., \& Zamani, M. (2016). Identification of the Relationship between Tourism Industry Development and Economic Growth of Zanjan Province. Journal of Urban Economics and Management, 4(15), 75-93.

Ospanov, G. M. (2012). Tourism in the Republic of Kazakhstan: current state and prospects of the development. Международный журнал экспериментального образования, 12(1), 24-28.

Saduov, A. Z. (2012). Issues of competitiveness of tourism industry of the republic of Kazakhstan. Education and Science without Borders, 4(6), 33-39.

Tiberghien, G. (2014). Authenticity and tourism in Kazakhstan: neo-nomadic culture in the post-Soviet era (Doctoral dissertation, Auckland University of Technology).

Tileuberdinova, A. T., \& Askeyev, A. G. (2012). Governmental regulation of the tourism industry in the Republic of Kazakhstan. Хабаршысы Вестник, 2, 66-70.

Tulbayeva, A., Abdikarimova, M., Ganitaev, M., Imangulova, T., \& Pestova, A. (2017). Optimization problems distribution of investments for the implementation strategy of domestic tourism in Kazakhstan. Revista ESPACIOS, 38, 37-44.

Valeev, R. M., \& Kadyrova, L. I. (2015). Formation and Development of Bilateral Relations of the Republic of Kazakhstan and the People's Republic of China in 1990-e-2000s. Journal of sustainable development, 8(4), 277-283. https://doi.org/10.5539/jsd.v8n4p277

Zhidkoblinova, O., Stavbunik, Y., \& Spanova, B. (2016). Public-Private Partnership as a Tool of Public Tourism Sector Administration. Journal of Environmental Management and Tourism, 7(2), 250-255. 


\section{Copyright Disclaimer}

Copyright for this article is retained by the author(s), with first publication rights granted to the journal.

This is an open-access article distributed under the terms and conditions of the Creative Commons Attribution license (http://creativecommons.org/licenses/by/3.0/). 